\title{
Epidemiology, molecular characterization and risk factors of Carnivore protoparvovirus-1 infection and disease in the wild felid Leopardus guigna in Chile
}

\author{
Irene Sacristán ${ }^{1}$, F. Esperon ${ }^{2}$, Ruben Pérez ${ }^{3}$, Francisca Acuña ${ }^{4}$, Emilio Aguilar ${ }^{4}$, Sebastian \\ Garcia $^{4}$, María José López ${ }^{4}$, Elena Neves ${ }^{5}$, Javier Cabello ${ }^{6}$, Ezequiel Hidalgo-Hermoso ${ }^{7}$, \\ Terio $\mathrm{KA}^{8}$, Javier Millan ${ }^{9}$, Elie Poulin ${ }^{10}$, and Constanza Napolitano ${ }^{11}$ \\ ${ }^{1}$ Universidad Andres Bello \\ ${ }^{2}$ CISA-INIA \\ ${ }^{3}$ Facultad de Ciencias \\ ${ }^{4}$ Universidad de Chile Facultad de Ciencias Veterinarias y Pecuarias \\ ${ }^{5}$ INIA-CISA \\ ${ }^{6}$ facultad de medicina veterinaria universidad san sebastian \\ ${ }^{7}$ Departamento de Conservación e Investigación, Parque Zoológico Buin Zoo \\ ${ }^{8}$ University of Illinois \\ ${ }^{9}$ Instituto Agroalimentario de Aragón-IA2 Universidad de Zaragoza-CITA \\ ${ }^{10}$ Universidad de Chile Facultad de Ciencias \\ ${ }^{11}$ Universidad de Los Lagos
}

June 18, 2020

\begin{abstract}
Landscape anthropization has been identified as one of the main drivers of pathogen emergence worldwide, facilitating pathogen spillover between domestic species and wildlife. The present study investigated Carnivore protoparvovirus-1 (CPPV) infection using molecular methods in 98 free-ranging wild guignas (Leopardus guigna) and 262 co-occurring owned, free-roaming rural domestic cats. We also assessed landscape anthropization variables as potential drivers of infection. CPPV DNA was detected in guignas across their entire distribution range, with observed prevalence of $13.3 \%$ (real-time PCR) and 9\% (conventional $\mathrm{PCR}$ ) in guignas, and $6.1 \%$ (conventional PCR) in cats. Prevalence in guigna did not vary depending on age, sex, study area or landscape variables. Prevalence was higher in juvenile cats (16.7\%) than in adults (4.4\%). Molecular characterization of the virus by amplification and sequencing of almost the entire vp2 gene (1746 bp) from one guigna and five domestic cats was achieved, showing genetic similarities to canine parvovirus 2c (CPV-2c) (one guigna and one cat), feline panleukopenia virus (FPV) (one cat), CPV-2 (no subtype identified) (two cats), CPV-2a (one cat). The CVP-2c-like sequence found in a guigna clustered together with domestic cat and dog CPV-2c sequences from South America, suggesting possible spillover from a domestic to a wild species as the origin of infection in guigna. No clinical signs of disease were found in PCR-positive animals except for the CPV-2c-infected guigna, which had hemorrhagic diarrhea and died a few days after arrival at a wildlife rescue center. Our findings reveal widespread presence of Carnivore protoparvovirus-1 across the guigna distribution in Chile and suggest that virus transmission potentially occurs from domestic to wild carnivores, causing severe disease and death in susceptible wild guignas.
\end{abstract}

\section{ABSTRACT}


Landscape anthropization has been identified as one of the main drivers of pathogen emergence worldwide, facilitating pathogen spillover between domestic species and wildlife. The present study investigated Carnivore protoparvovirus-1 (CPPV) infection using molecular methods in 98 free-ranging wild guignas (Leopardus guigna ) and 262 co-occurring owned, free-roaming rural domestic cats. We also assessed landscape anthropization variables as potential drivers of infection. CPPV DNA was detected in guignas across their entire distribution range, with observed prevalence of $13.3 \%$ (real-time PCR) and 9\% (conventional PCR) in guignas, and $6.1 \%$ (conventional PCR) in cats. Prevalence in guigna did not vary depending on age, sex, study area or landscape variables. Prevalence was higher in juvenile cats (16.7\%) than in adults (4.4\%). Molecular characterization of the virus by amplification and sequencing of almost the entire vp2 gene (1746 bp) from one guigna and five domestic cats was achieved, showing genetic similarities to canine parvovirus 2c (CPV-2c) (one guigna and one cat), feline panleukopenia virus (FPV) (one cat), CPV-2 (no subtype identified) (two cats), CPV-2a (one cat). The CVP-2c-like sequence found in a guigna clustered together with domestic cat and dog CPV-2c sequences from South America, suggesting possible spillover from a domestic to a wild species as the origin of infection in guigna. No clinical signs of disease were found in PCR-positive animals except for the CPV-2c-infected guigna, which had hemorrhagic diarrhea and died a few days after arrival at a wildlife rescue center. Our findings reveal widespread presence of Carnivore protoparvovirus-1 across the guigna distribution in Chile and suggest that virus transmission potentially occurs from domestic to wild carnivores, causing severe disease and death in susceptible wild guignas.

KEYWORDS : Leopardus guigna ; domestic cats; infectious diseases; landscape drivers; Canine parvovirus; Feline panleukopenia virus.

\section{1 . INTRODUCTION}

Inhabiting human-dominated landscapes has been considered a risk factor for higher pathogen prevalence in wildlife (Riley et al., 2004; Foley et al., 2013; Carver et al., 2015; Millán et al., 2016). Anthropogenic factors including habitat loss and fragmentation, conversion of natural habitats and close human presence facilitate pathogen spillover at the wildlife-domestic interface (Foley et al., 2013) and potentially impact the survival of wildlife populations. Examples of how pathogens threaten wild carnivore populations of conservation concern include canine distemper virus in African wild dogs, Lycaon pictus (Alexander and Appel, 1994; Laurenson et al., 1998), lions, Panthera leo(Harder et al., 1995; Roelke-Parker et al., 1996) and black-footed ferrets, Mustela nigripes (Thorne and Williams, 1988); rabies in Ethiopian wolf, Canis sinensis (Sillero-Zubiri et al., 1996); and feline leukemia virus (FeLV) in Iberian lynx, Lynx pardinus ( Meli et al., 2009) and Florida panther, Puma concolor coryi (Chiu et al., 2019).

Rapid native forest habitat conversion has taken place in Chile over the past two to three decades, especially affecting those animal species that rely on vegetation cover (Wilson et al., 2005; Echeverría et al., 2006; Echeverría et al., 2008; Schulz et al., 2010; Heilmayr et al., 2016). Pathogen spillover at the wildlife-domestic interface may occur in these human-dominated landscapes. The forest-dwelling wild felid guigna (Leopardus guigna ) is endemic to Chile and a small strip of southwestern Argentina and classified as Vulnerable by the IUCN (Napolitano et al., 2015a). Guigna populations have experienced a rapid decline, mainly due to habitat loss and fragmentation (Napolitano et al., 2015a). A previous study (Mora et al., 2015) found that guignas inhabiting human-dominated landscapes are infected by feline leukemia virus and feline immunodeficiency virus, possibly transmitted by domestic cats, supporting the hypothesis of infectious diseases as potential threats for this species. Further information on other pathogens infecting guignas in human-dominated landscapes is scarce, and include the report of hemoplasmas (Sacristan et al., 2019).

Another group of multi-host pathogens that infect mammals is theCarnivore protoparvovirus-1 (CPPV hereafter), which belongs to the family Parvoviridae, subfamily Parvovirinae. According to the most recent taxonomy, subfamily Parvovirinae is composed of eight different genera: Amdoparvovirus, Aveparvovirus ,Bocaparvovirus , Copiparvovirus, Dependoparvovirus, Erythroparvovirus, Protoparvovirus and Tetraparvovirus(Cotmore et al., 2014). The CPPV of the genus Protoparvovirusinfects a broad range of domestic and wild species and is present in almost all wild and domestic carnivore populations tested (Steinel et al., 2001; Alison et al., 2013; Duarte et al., 2013; Rubio et al., 2013; Cotmore et al., 2014; Acosta-Jamett et al., 2015a; 
Calatayud et al., 2019a,b). There are four recognized CPPV viral variants: feline panleukopenia (FPV), canine parvovirus (CPV), mink enteritis virus (MEV) and raccoon parvovirus (RaPV) (Cotmore et al., 2014). Studies have suggested that the CPV in dogs (initially known as CPV-2 to differentiate it from minute virus of canines [CPV-1, genusBocaparvovirus ], originated from the feline panleukopenia virus following crossspecies transmission from felids or other carnivore hosts (i.e. minks, foxes or raccoons) (Truyen et al., 1996; Shackelton et al., 2005; Parrish et al., 2008; Allison et al., 2013). The appearance of CPV-2 in a novel host - domestic dogs - in Europe in the mid-1970s is a clear example of emerging diseases, nowadays considered a pandemic (Parrish and Kawaoka, 2005; Parrish et al., 2008). The original CPV-2 only infected dogs but was soon completely replaced by a new lineage that initially included two different antigenic variants, CPV type-2a (CPV-2a) and CPV type-2b (CPV-2b) (Parrish et al., 1985,1988, 1991). These variants recovered the ability to infect felids, lost by the original variant (CPV-2), and have been associated with increasing pathogenicity (Decaro and Buonavoglia, 2012, Allison et al., 2013). In contrast to FPV, the merging CPV-2 showed rapid evolution, with substitution rates similar to RNA viruses (Shackelton et al., 2005). The newest viral variant (CPV-2c) was discovered in Italy in 2000 (Buonavoglia et al., 2001), and rapidly spread to canine populations worldwide (Nakamura et al., 2004; Decaro et al., 2007, 2006; Hong et al., 2007; Kapil et al., 2007; Pérez et al., 2007; Calderon et al., 2009; Touihri et al., 2009) and to wildlife (Calatayud et al., 2019 a,b).

CPPV require the nucleus of rapidly dividing cells for replication (e.g. intestinal crypts, myocardiocytes and bone marrow precursor cells), thus it mainly affects young animals (Goddard and Leisewitz, 2010; Decaro and Buonavoglia, 2012). However, CPV-2c has been associated with severe disease in adults, even in vaccinated animals (Decaro and Buonavoglia, 2012). The main clinical signs of CPV infection in dogs are hemorrhagic enteritis, anorexia, vomiting, fever, depression and leukopenia. The mortality rate in pups may exceed $70 \%$ (Decaro and Buonavoglia, 2012). The pathogenesis of CPV in cats is unclear, although CPV-2a and CPV-2b infection pathogenesis appears to be similar to FPV (Mochizuki et al., 1996). Domestic cats infected by CPV$2 \mathrm{c}$ in Italy presented mild forms of the disease without abnormal hematological findings (Decaro et al., 2011). Cheetahs and tigers infected by CVP-2a/2b-type had chronic diarrhea, enteritis and anorexia, suggesting high pathogenic potential of these viral variants in felids (Steinel et al., 2000). FPV affects cats of all ages, but kittens are more susceptible, with mortality rates over $90 \%$ (Truyen et al., 2009). The main clinical signs are diarrhea, lymphopenia and neutropenia, followed by thrombocytopenia and anemia, immunosuppression (transient in adult cats), abortion and cerebellar ataxia in kittens (Truyen et al., 2009).

One of the main characteristics of CPPV is its high environmental stability and survival, conferring capacity of transmission by both direct and indirect contact with infected animals, as well as by environmental contamination (Berthier et al., 2000). Intrauterine transmission has also been documented (Truyen et al., 2009). The fecal-oral route is considered as the main transmission method (Truyen et al., 2009).

Exposure to CPPV in Chile has been detected only by serological methods in domestic cats and dogs (AcostaJamett et al., 2015a, 2015b; Llanos-Soto et al., 2019). FPV exposure or infection have not been reported in Chilean wild species, while antibodies against CPV have been reported in gray fox (Lycalopex griseus ) and culpeo fox (L. culpaeus ) (Rubio et al., 2013; Acosta-Jamett et al., 2015a). There is no available information on the potential pathogenic effects of CPPV on wild carnivore species in Chile or information about exposure or infection in the guigna.

Here we identified potential disease risk factors associated with CPPV in guignas and their domestic counterpart, the cat, modelled possible transmission pathways and conducted phylogenetic analysis of strains of wild and domestic felids in Chile. We also assessed the clinical status and potentially associated lesions of CPPV-infected guignas by histopathology and hematological analysis. Our goal was to evaluate the possible effects of landscape anthropization on the interspecific transmission of CPPV between guignas and domestic cats as well as to evaluate possible pathogenicity of CPPV in guignas.

\section{MATERIAL AND METHODS}

\subsection{Study area}


The study area included different macro-regions of central and southern Chile ( $\left.33^{\mathrm{o}} \mathrm{S}-46^{\mathrm{o}} \mathrm{S}\right)$, encompassing the entire current distribution range of the guigna in Chile (Napolitano et al., 2015a) (Figure 1). We defined four study areas: Central, South, Chiloé Island and Austral areas, which correspond to the phylogeographic structure of guigna populations (Napolitano et al., 2014). The study area has different degrees of humandominated landscapes, including continuous near pristine forest areas and areas with high human population density (INE, 2017).

\subsection{Sample collection}

Between 2008 and 2018, 98 free-ranging guignas were sampled, through active capture with tomahawk-like live traps $(n=48)$ or opportunistically immediately following admission into wildlife rescue and rehabilitation centers (WRRC; $n=8)$, euthanized at WRRC $(n=4)$, or found road-killed $(n=38)$.

Captured animals were immobilized with a combination of dexmedetomidine $(0.05 \mathrm{mg} / \mathrm{kg})$ and ketamine $(5 \mathrm{mg} / \mathrm{kg})$ injected intramuscularly. When the guigna started to regain consciousness, an intramuscular injection of atipamezole (five times the dose of dexmedetomidine previously applied) was given to antagonize the dexmedetomidine. The anesthetic protocol was adapted from protocols described in other species of South American wild felids (Beltrán et al., 2009).

Whole blood samples were collected from live animals by jugular venipuncture from 55 guignas $(0.5 \mathrm{ml}$ tube with EDTA anticoagulant for genetic analysis, $0.5 \mathrm{ml}$ EDTA anticoagulant tube for hematological analysis, $1 \mathrm{ml}$ tube without anticoagulant for biochemical analysis). Fecal samples were collected directly from the rectum of 20 guignas and preserved frozen $\left(-20{ }^{\circ} \mathrm{C}\right)$. Complete necropsies of road-killed and euthanized animals (at WRRC) were performed and fecal $(n=31)$, spleen $(n=27)$, intestine $(n=8)$ and thoracic blood $\operatorname{samples}(n=7)$ were collected.

Sex, age range (estimated from dentition) and GPS location of each animal sampled were recorded. All live animals were given a complete physical examination by a veterinarian. A total of 38 females and 60 males, 62 adults and 16 juveniles (no age data was available for 20 individuals) were sampled.

Whole blood ( $n=258)$ ( $0.5 \mathrm{ml}$ tubes with EDTA anticoagulant for genetic analysis) and/or feces directly collected from the rectum $(n=83)$ were also collected from 262 owned, free-roaming domestic cats from rural communities across the guigna distribution range in Chile. Four spleen samples were collected during necropsies of road-killed domestic cats. Sex, age class and location of each cat were recorded. A total of 129 females and 133 males, 226 adults and 36 juveniles were sampled. None of the cats was vaccinated (no information available for the four road-killed cats) or neutered.

Guigna captures and tissue collection followed proven techniques (Napolitano et al., 2015b), and handling and supervision protocols in accordance with bioethical and animal welfare frameworks, with permission from the Chilean Agriculture and Livestock Service (SAG) (capture permits 814/13 2008, 109/9 2009, 1220/22 2010, 1708/26 2010, 7624/2015, 2288/2016, 2185/2017, 4072/2018). All procedures followed animal welfare and ethical protocols previously approved by the Animal Ethics Committee of the Institute of Ecology and Biodiversity of Universidad de Chile (resolution of November 20, 2015).

Guigna and domestic cat samples were stored frozen at $-20 \operatorname{deg} C$ until molecular analyses. Samples for hematological and biochemical analysis were stored refrigerated and sent to the laboratory within two days of collection.

\subsection{Genetic analysis}

Total DNA extraction from guigna blood, fecal and tissue samples was performed by a pressure filtration method (QuickGene DNA Tissue Kit S, Fujifilm, Japan), following the manufacturer's instructions. Domestic cat DNA extraction from blood, fecal and tissue samples was performed with a commercial kit (DNeasy Blood \& Tissue kit, Qiagen(r), Germany), following the manufacturer's instructions. To monitor for crosscontamination during the extraction process, negative controls consisting of $100 \mu$ phosphate-saline buffer were prepared concurrently with each batch of 15 samples. 
Ultrapure water was used as a negative control in all PCR assays. The commercial CPV-2 vaccine (Nobivac@) Puppy DP, MSD Animal Health, Carbajosa de la Sagrada, Spain) was used as a positive control for guigna sample analysis and a sequenced PCR-positive domestic dog was employed as positive control for domestic cat sample analysis.

DNA amplification of CPPV from guigna samples was performed by a conventional PCR adapted from Streck et al. (2013) and also by real-time PCR method based on TaqMan probes for comparison purposes, amplifying 200 bp of the parvovirus vp2 gene of both CPV-2 and FPV, as previously described by Streck et al. (2013).

DNA amplification of CPPV from domestic cat samples was performed according to Streck et al. (2013), adapted to conventional PCR $\left(95^{\circ} \mathrm{C}, 5\right.$, followed by 40 cycles: $95{ }^{\circ} \mathrm{C} 30 "$; $58^{\circ} \mathrm{C} 30 " ; 7{ }^{\circ} \mathrm{C}$, 30 "; with a final extension of $72^{\circ} \mathrm{C}$ for $7^{\prime}$ ), amplifying $200 \mathrm{bp}$ of the vp2 gene.

Molecular characterization of positive guignas and domestic cats after the screening stage was carried out by amplifying and sequencing almost the entire vp2 gene, a procedure regarded as the gold standard for this pathogen (Truyen et al., 1996). A nested PCR was performed to amplify $1746 \mathrm{bp}$. The external PCR amplified a 2401 bp fragment, and was conducted by combining primers VPF and M5mod (Mochizuki et al., 1996; Steinel et al., 2000); the internal PCR was conducted using primers P1 and VPR (Mochizuki et al., 1993; Battilani et al., 2001) (Table 1). The temperature profile for the external PCR was set at $94{ }^{\circ} \mathrm{C}$ for $5^{\prime}$, followed by 45 cycles: $94^{\circ} \mathrm{C}$ for $30^{\prime \prime}, 55^{\circ} \mathrm{Cfor} 30^{\prime \prime}$ and $72^{\circ} \mathrm{C}$ for 2 ' $30^{\prime \prime}$, with a final extension of $72^{\circ} \mathrm{C}$ for $7^{\prime}$ '. The internal PCR was set at $94{ }^{\circ} \mathrm{C}$ for 5 , followed by 40 cycles: $94^{\circ} \mathrm{C}$ for 15 ", $52^{\circ} \mathrm{C}$ for 15 " and $72^{\circ} \mathrm{C}$ for $2^{\prime}$, with a final extension of $72^{\circ} \mathrm{C}$ for $7^{\prime}$. Samples with the corresponding $1746 \mathrm{bp}$ amplicon were sequenced with eight different primers (Table 1). PCR products were separated by electrophoresis in $2 \%$ agarose gels and directly sequenced by Sanger methods.

Multiple sequence alignments were conducted using the CLUSTAL W algorithm (Geneious( ) ). The best model of evolution was selected by the jModelTest2 (version 2.1.6) program (Darriba et al., 2012), under the Akaike Information Criterion (AIC) (Posada and Buckley, 2004). Phylogenetic trees were constructed based on Bayesian and maximum likelihood methods (MrBayes 3.1.2 (Ronquist and Huelsenbeck, 2003); RaXML software version 1.5 (Stamatakis et al., 2008). The data set was resampled 1000 times to generate bootstrap values.

\subsection{Spatial variable analysis}

To describe the landscape features associated with CPPV infection in guigna, we generated a circular area surrounding each guigna sample location, which was defined as the buffer area. This buffer corresponded to the mean home range area described for guignas (males=446 ha; females=170 ha) (Dunstone et al., 2002; Sanderson et al., 2002; Schüttler et al., 2017). We described and quantified six landscape variables in each buffer area,: 1) percentage of vegetation cover (Hansen et al., 2013, v.1.4), 2) presence of houses within the buffer, 3) number of houses within the buffer, 4) distance from the sample location to the nearest house (either inside or outside the buffer area), 5) land use (fragmented landscape or continuous forest) and 6) study area: Central, South, Chiloé Island and Austral area.

Percent vegetation cover was defined based on Hansen et al. (2013, v.1.4), which included canopy closure for all vegetation greater than $5 \mathrm{~m}$ height in both native and timber plantations (both native and timber plantations suppose functional connectivity for guignas) (Sanderson et al., 2002; Gálvez et al., 2013, 2018).

Presence of houses and number of houses were defined based on the presence of roofs extracted from Google Earth (Google Inc.2013), using roofs as a proxy for houses (Villatoro et al., 2016).

For land use (variable 5), we defined continuous landscape as a buffer area composed only of continuous vegetation, which may or may not include roads (functional connectivity for guignas is not limited by roads) (Sanderson et al., 2002; Gálvez et al., 2013, 2018). We defined a fragmented landscape as a buffer area composed of human settlements, agricultural land and/or fragments of forest surrounded by a matrix of human activities. 
GIS layers were obtained from the Ministerio de Bienes Nacionales website (Ministerio de Bienes Nacionales, 2019). The QGIS 2.14@ software was used to extract the attribute values of landscape variables corresponding to each sampled guigna for spatial analysis. To address spatial autocorrelation in our data, we conducted a Global Moran I test (Pfeiffer et al., 2008) using ArcGIS Pro. We obtained non-significant results (Moran's index $=0.38$, z-score $=0.46, p$-value $=0.64$ ), suggesting that there is no pattern of data spatial clustering.

\subsection{Assessment of clinical signs of disease}

Guigna hematological, biochemical and histological parameters were evaluated, as well as clinical signs, by direct inspection. Guigna whole blood preserved in EDTA $(n=20)$ and serum samples $(n=19)$ were submitted to hematological and biochemical analysis, respectively. The hematological parameters analyzed included erythrocyte count (RBC), white blood cell count (WBC), hemoglobin concentration, mean cell volume (MCV), mean corpuscular hemoglobin concentration (MCHC) and hematocrit determination, using the Abacus Junior Vet Analyzer (Diatron@). The biochemical parameters evaluated were glucose, total protein, albumin, globulin, total bilirubin, total cholesterol, blood urea nitrogen, creatinine, calcium, phosphorus, alanine aminotransferase, aspartate aminotransferase and gamma glutamyl transferase, analyzed by Microlab 100 of MERCK@, employing Wienerß Lab products.

Histopathological analysis was performed in tissue samples collected during the necropsies of 32 guignas. Histopathological evaluation was performed on formalin-fixed tissues embedded in paraffin wax, sectioned at $3-5 \mu \mathrm{m}$ and stained with hematoxylin eosin (HE).

\subsection{Statistical analysis}

Spatial and biological variables associated with CPPV infection were assessed with crude and adjusted odds ratios (ORs) calculated by a logistic regression analysis with $95 \%$ confidence intervals (CIs) The goodness of fit models were assessed using the Hosmer Lemeshow test and analysis of residuals (Hosmer et al., 2008)

Differences in infection prevalence between domestic cats and guignas, as well as between biogeographic regions, were analyzed using non-parametrical tests, either Mann-Whitney U or Kruskal-Wallis (Zar, 1999). Hematological and biochemical parameters of infected and non-infected guignas were compared by KruskalWallis tests. All statistical analyses were performed in R studio software 3.0.1 (R Core Team, 2013) with a significance level of $p<0.05$.

\section{RESULTS}

DNA of CPPV was detected in 13/98 guignas (13.3\%, 95\% Confidence Interval (C.I.) $=6.4 \%-20.1 \%)$ using real-time PCR method and 9/98 guignas $(9.1 \%$, C.I. $=3.3-15.0 \%)$ using conventional PCR. Comparing between real-time PCR and conventional PCR, the latter was able to detect $4.1 \%$ less CPPV positive guignas than real-time PCR. DNA of CPPV was detected in 16/262 (6.1\%, C.I. $=3.1-9.0 \%)$ of domestic cats (conventional PCR) (Table 2). Differences in guignas and domestic cats by conventional PCR methods were not statistically significant $(p=0.30 ; U=12440)$.

No statistically significant differences in CPPV prevalence were observed in guignas in relation to sex, age, study area or landscape variables (Table 2 and 3, Figure 2). A significantly higher prevalence was found in juvenile domestic cats $(16.7 \%)$ compared to adults $(4.4 \%)(U=3570 ; p=0.004)$. No statistically significant difference was found according to study area $(K=4.04 ; p=0.25)$ or $\operatorname{sex}(U=8301 ; p=0.27)$ in domestic cats (Table 2). No association between CPPV prevalence and year of sampling was found in guignas or domestic cats $(K=3.18, p=0.21 ; K=6.828, p=0.07)$.

Sampled guignas showed low rtPCRct (cycle threshold) values, with 12/13 samples presenting values under 28.5 (Table 3). The lowest ct value (25.67) corresponded to a juvenile female guigna which showed clinical signs of disease at the time of sampling. This juvenile female was admitted into a WRRC with hemorrhagic diarrhea, anorexia and cachexia; she died four months after admission. Unfortunately, hematological and biochemical parameters and postmortem examination were not available from this individual. No clinical signs were observed in any of the other positive guignas or domestic cats. 
No differences in hematological or biochemical parameter values were found comparing PCR-positive to PCR-negative guignas (Tables 5 and 6). However, one PCR-positive guigna presented hematological alterations (anemia, leukocytosis, lymphocytosis) (based on parameters of Geoffroy's cat, Leopardus geoffroyi, the species most closely related genetically to the guigna (Teare, 2002), compatible with an infectious process (Tables 7 and 8). Histopathological analysis comparing PCR-positive and PCR-negative guignas did not reveal any lesions consistent with active $\mathrm{CPPV}$ infection in the former.

Despite repeated attempts, molecular characterization of the vp2gene was successful only in one PCR-positive guigna sample and 5 domestic cat samples, possibly due to low pathogen loads in samples or suboptimal quality of field samples.

Comparing the sequence from this positive guigna (LG145 GenBank accession number MT367584) with sequences deposited in GenBank, we found $99.4 \%$ nucleotide similarity with CPV-2c from a domestic dog in Mexico (GenBank accession number KY818892). Domestic cat sequences presented 99.6\% nucleotide similarity with CPV-2c identified from Mexican domestic dogs (GenBank accession number KY818854) (GDAY17; GenBank accession number MT367582), 100\% nucleotide similarity with FPV detected in an Australian domestic cat (GenBank accession number X55115) (GDNH15; MT367581), and 99.6\%-99.9\% nucleotide similarity with CPV-like amplified in several raccoon dogs (Nyctereutes procyonoides) (e.g. GenBank accession number MH581185) from China (GDNH21; MT367580) and a domestic dog (GenBank accession number KY921606) from Mexico (15038; MT367583), and 99.8\% nucleotide similarity with CPV-2a from an Argentinian domestic dog (GenBank accession number KM236573) (GDRM19; MT367579) (Table 4).

Phylogenetic analysis showed well-supported clades; sequences of one guigna and one domestic cat from this study clustered in the CPV-2c clade (GDAY17). Two domestic cats from this study clustered in the CPV-2a clade (GDRM19 and 15028), one domestic cat clustered in the FPV clade (GDNH15), and another domestic cat sequence belonged to a CPV-2 clade intermediate between the CPV-2a and 2c clades (GDNH21) (Figures 3 and 4$)$.

\section{DISCUSSION}

CPPV is known to infect a wide range of wild carnivores, including wild felids (Steinel et al., 2001; Duarte et al., 2013; Rubio et al., 2013; Cotmore et al., 2014; Acosta-Jamett et al., 2015a; Calatayud et al., 2019 a, b). However, most studies on wildlife have been conducted on animals in captive settings; studies on free-ranging felids are scarce (Hofmann-Lehmann et al., 1996; Steinel et al., 2001, Filoni et al., 2006; Santos et al., 2009; Calatayud et al., 2019a).

The present study showed relatively high CPPV DNA observed prevalence (13.3\%) in guigna, with widespread occurrence across the species' distribution range in Chile. A study based on molecular analysis in a wild felid found $13.7 \%$ prevalence of FPV in lions (Panthera leo ) from Tanzania; FPV is considered an endemic pathogen in this population (Calatayud et al., 2019a). The only infection with CPV-2c was detected in a wildcat (Felis silvestris silvestris) from the Iberian Peninsula (Calatayud et al., 2019b).

Based on serology, Filoni et al. (2006), found parvovirus seroprevalence of $48 \%$ in ocelot (Leopardus pardalis), cougar, (Puma concolor ), and tigrillo (Leopardus tigrinas), from Brazil. In free-ranging lions from Serengeti National Park, high seroprevalence of parvovirus (78\%) related to a possible outbreak was found (HofmannLehmann et al., 1996), being lower in the Ngorongoro Crater area (27\%). Canine parvovirus antibodies were detected in four of 22 and one of eight studied wildcats from Spain and Portugal, respectively ((Millán and Rodríguez, 2009, Santos et al., 2009).

The observed prevalence of CPPV reported here in domestic cats of Chile (6.1\%) was lower than that described in other South American domestic cat populations (11.8\% FPV prevalence in Brazil; de Cássia et al., 2011), or in Europe (32.5\% CPV prevalence in domestic cats from UK; Clegg et al., 2012), both through conventional PCR methods, supporting a limited infection rate of this virus in central-southern Chile. To the authors' knowledge, this is the first molecular report of CPPV in domestic cats from Chile.

Higher observed CPPV DNA prevalence in juvenile vs. adult domestic cats may be explained by the fact that 
CPPV replicates in rapidly divided cells, thus affecting mainly young animals. and could also be related to an endemic status of infection in domestic cats (Goddard and Leisewitz, 2010; Decaro and Buonavoglia, 2012). In guignas, no statistically significant differences were observed between age classes. Absence of statistically significant differences may be due to low sample size and thus low statistical power; a greater sample size would be necessary to detect statistically significant differences. However, the lack of difference between age classes could indicate that that CPPV infection in guignas is not endemic and spillover process are occurring. We advise the use of real-time PCR methods for the detection of CPPV instead of conventional PCR, given its higher sensitivity for viral DNA detection ( $13.3 \% \mathrm{rtPCR}$ vs . $9.1 \%$ conventional PCR), additionally providing a relative quantification of viral load. Although the pathogenicity capacity of CPPV in wild felids is still poorly understood (Ikeda, 2002), high mortality from both CPV and FPV in young animals has been documented in domestic dogs and cats (Truyen et al., 2009; Decaro and Buonavoglia, 2012).

Low ct (under 28) was obtained in most rtPCR positive animals, suggesting that in most cases the infection was probably subclinical. The only guigna that showed clinical signs consistent with parvovirosis was infected by the CPV-2c subtype, the most recently emerged CPV viral type, also identified as the most pathogenic one. This may imply that this viral type infection may produce severe pathogenicity in wild felids (Decaro et al., 2011; Ikeda, 2002), which should be taken into consideration in future surveillance.

Only one of the domestic cat sequences was identical to FPV; the other four were phylogenetically related to CPV sequences. Although FPV is the most prevalent species of parvovirus infecting cats and has been considered endemic in some populations of wild felids (Truyen et al., 2009; Battilani et al., 2011; Calatayud et al., 2019a), in the present study only one sequence belonged to this virus type, differing from results obtained in other countries where CPV infection in cats is rare and sporadic (Truyen et al., 2009, Battilani et al., 2011).

Considering that CPV infection is unusual in felids (Calatayud et al., 2019a,b), its possible origin in guignas and domestic cats of this study may be cross-species transmission from domestic dogs or other wild canids. Free-ranging domestic dogs are abundant in rural Chile and are not usually subjected to any sanitary control or movement restriction, roaming freely in natural areas and therefore facilitating contact possibilities with domestic and wild species (Villatoro et al., 2016) and spreading of dog infectious agents, thus dogs may be the most probable origin of infection in guignas. High environmental survival of CPPV may allow the possibility of wildlife being in contact with the virus for several months, even in the absence of direct animal contact (Berthier et al., 2000). Likewise, the ability of the virus to survive in the environment may explain its wide distribution across the study area.

The results of this study reveal widespread presence of CPPV across the guigna distribution in Chile and confirm that interspecific transmission of the virus may occur from domestic to wild carnivores, being capable of causing severe disease and fatal infections in wild guignas. Although the impact of CPPV infection in guigna populations is still unclear, elucidating the dynamics of pathogen transmission between domestic and wild species is essential to enable the implementation of integrative management measures to prevent negative effects for the long-term survival of wildlife populations.

\section{ACKNOWLEDGEMENTS}

We gratefully acknowledge local inhabitants of rural communities for kindly giving us the opportunity to sample their domestic cats. We are grateful to CONAF, especially Patricio Contreras, Patricia Barría, Andrea Bahamonde and Dennis Aldrigde; SAG, especially Diego Ramírez and Rodrigo Villalobos; the Ministry of the Environment, especially Sandra Díaz; Tantauco Park, especially Alan Bannister and Catherine Chirgwin; and the Valdivian Coastal Reserve and Camila Dünner for logistic support. Special thanks to Debora Mera, Diego Peñaloza, Gonzalo Canto, Camila Núñez, Héctor Basualto, Nicolás Gálvez, Eduardo Silva, Maximiliano Sepúlveda, José Luis Brito, Daniel González, Nicole Sallaberry, Angelo Espinoza, Jorge Valenzuela, Daniela Poo, Francisca Astorga, Violeta Barrera, Macarena Barros, Gonzalo Medina, Claudia Hernández, Nora Prehn, Camila Sepúlveda, Gerardo Morales, Daniela Ormazával, Pía Astudillo, Andrea Roa, Gaby Svensson, Ricardo Pino, Frederick Toro, Elfego Cuevas, Mario Alvarado, Brayan Zambrano, Tomás Valdés 
and Manuel Valdés for their valuable support in sample collection. Our work was funded by CONICYT FONDECYT Iniciación 11150934 (CN), Morris Animal Foundation D15ZO-413 (CN), National Geographic Society C309-15 (CN), Mohamed bin Zayed Species Conservation Fund 152510351 (CN), 2018 Endeavour Research Fellowship (Australian government) (CN), CONICYT PAI 77190064 (CN), CONICYT PIA APOYO CCTE AFB170008 (CN, EP), the Wild Felid Association (IS), Fondo Interno UNAB DI-778-15/R (JM), Morris Animal Foundation D16Z-825 (JM), and CONICYT FONDECYT Regular 1161593 (JM, CN).

6. CONFLICT OF INTEREST STATEMENTThe authors declare no competing interests.

\section{DATA AVAILABILITY STATEMENT}

The genetic data that support the findings of this study are openly available in Genebank, at https://www.ncbi.nlm.nih.gov/genbank, reference numbers: MT367584, MT367582, MT367581, MT367580, MT367579, MT367583. Other data that support the findings of this study are available from the corresponding author upon reasonable request.

\section{REFERENCES}

Acosta-Jamett, G., Cunningham, A. A., Bronsvoort, B. M. deC., \& Cleaveland, S. (2015a). Serosurvey of canine distemper virus and canine parvovirus in wild canids and domestic dogs at the rural interface in the Coquimbo Region, Chile. European Journal of Wildlife Research , 61 (2), 329-332.

Acosta-Jamett, G., Surot, D., Cortés, M., Marambio, V., Valenzuela, C., Vallverdu, A., \& Ward, M. P. (2015b). Epidemiology of canine distemper and canine parvovirus in domestic dogs in urban and rural areas of the Araucanía region in Chile. Veterinary Microbiology ,178 (3), 260-264.

Alexander, K. A., \& Appel, M. J. (1994). African wild dogs (Lycaon pictus ) endangered by a canine distemper epizootic among domestic dogs near the Masai Mara National Reserve, Kenya. Journal of Wildlife Diseases , 30 (4), 481-485.

Allison, A. B., Kohler, D. J., Fox, K. A., Brown, J. D., Gerhold, R. W., Shearn-Bochsler, V. I., Dubovi, E.J., Parrish, C.R., Holmes, E. C. (2013). Frequent Cross-Species Transmission of Parvoviruses among Diverse Carnivore Hosts. Journal of Virology , 87 (4), 2342-2347.

Battilani, M, Scagliarini, A, Tisato, E., Turilli, C., Jacoboni, I., Casadio, R., \& Prosperi, S. (2001). Analysis of canine parvovirus sequences from wolves and dogs isolated in Italy. The Journal of General Virology , 82 (Pt 7), 1555-1560.

Battilani, Mara, Balboni, A., Ustulin, M., Giunti, M., Scagliarini, A., \& Prosperi, S. (2011). Genetic complexity and multiple infections with more Parvovirus species in naturally infected cats. Veterinary Research , $42(1), 43$.

Beltrán, S., Fabián, L., Nallar, G., Villalba, M., Lilian, M., Delgado, E., \& Berna, M. (2009). Inmovilización química, evaluación hematológica y coproparasitología de Leopardus colocolo en Khastor, Potosí, Bolivia. Revista de Investigaciones Veterinarias Del Perú ,20 (2), 297-305.

Behdenna, A., Lembo, T., Calatayud, O., Cleaveland, S., Halliday, J. E., Packer, C., \& Dobson, A. P. (2019). Transmission ecology of canine parvovirus in a multi-host, multi-pathogen system. Proceedings of the Royal Society of London, 286 (1899), 20182772.

Berthier, K., Langlais, M., Auger, P., \& Pontier, D. (2000). Dynamics of a feline virus with two transmission modes within exponentially growing host populations. Proceedings of the Royal Society of London. Series B: Biological Sciences , 267 (1457), 2049-2056.

Buonavoglia, C., Martella, V., Pratelli, A., Tempesta, M., Cavalli, A., Buonavoglia, D., Bozzo, G., Elia, G., Decaro, N., Carmichael, L. (2001). Evidence for evolution of canine parvovirus type 2 in Italy.Journal of General Virology , 82 (12), 3021-3025. 
Calatayud, O., Esperón F., Cleveland S., Biek R., Keyyu J., Eblate E., Neves E., Lembo T., Lankester F. (2019a). Carnivore parvovirus ecology in the Serengeti ecosystem: vaccine strains circulating and new host species identified. Journal of Virology . 93 (13), e02220-18.

Calatayud, O., Esperón F., Velarde, R., Oleagas, A., Llanezas L., Ribas, A., Negres, N., de la Torre, A., Rodríguez, A., Millán, J. (2019b). Genetic characterization of Carnivore Parvoviruses in Spanish wildlife reveals domestic dog and cat-related sequences. Transboundary and Emerging Diseases , 67 (2), 626-634.

Calderon, M. G., Mattion, N., Bucafusco, D., Fogel, F., Remorini, P., \& La Torre, J. (2009). Molecular characterization of canine parvovirus strains in Argentina: Detection of the pathogenic variant CPV2c in vaccinated dogs. Journal of Virological Methods , 159 (2), 141-145.

Carver, S., Bevins, S. N., Lappin, M. R., Boydston, E. E., Lyren, L. M., Alldredge, M. W., Logan, K.A., Sweanor, L.L., Riley, S.P.D., Serieys, L.E.K., Fisher, R.N., Vickers, T.W., Boyce, W.M., McBride, R., Cunningham, M.C., Jennings, M., Lewis, J.S., Lunn, T., Crooks, K.R., VandeWoude, S. (2015). Pathogen exposure varies widely among sympatric populations of wild and domestic felids across the United States.Ecological Applications , 150707213506001 .

Chiu, E. S., Kraberger, S., Cunningham, M., Cusack, L., Roelke, M., \& VandeWoude, S. (2019). Multiple Introductions of Domestic Cat Feline Leukemia Virus in Endangered Florida Panthers. Emerging Infectious Diseases , 25 (1), 92-101.

Clegg, S. R., Coyne, K. P., Dawson, S., Spibey, N., Gaskell, R. M., \& Radford, A. D. (2012). Canine parvovirus in asymptomatic feline carriers. Veterinary Microbiology , 157 (1-2), 78-85.

Cotmore, S. F., Agbandje-McKenna, M., Chiorini, J. A., Mukha, D. V., Pintel, D. J., Qiu, J., SoderlundVenermo, M., Tattersall, P., Tijssen, P., Gatherer, D. (2014). The family parvoviridae. Archives of Virology , 159 (5), 1239-1247.

Darriba, D., Taboada, G. L., Doallo, R., \& Posada, D. (2012). jModelTest 2: More models, new heuristics and parallel computing.Nature Methods, 9 (8), 772.

de Cássia Nasser Cubel Garcia, R., de Castro, T. X., de Miranda, S. C., Júnior, G. L., de Lima, M., Labarthe, N. V., \& Gagliardi Leite, J. P. (2011). Characterization of parvoviruses from domestic cats in Brazil.Journal of Veterinary Diagnostic Investigation, 23 (5), 951-955.

Decaro, N., Martella, V., Desario, C., Bellacicco, A. L., Camero, M., Manna, L., L., d'Aloja., Buonavoglia, C. (2006). First detection of canine parvovirus type 2c in pups with haemorrhagic enteritis in Spain. Journal of Veterinary Medicine, Series B , 53 (10), 468-472.

Decaro, Nicola, \& Buonavoglia, C. (2012). Canine parvovirus - A review of epidemiological and diagnostic aspects, with emphasis on type 2c. Veterinary Microbiology , 155 (1), 1-12.

Decaro, Nicola, Desario, C., Addie, D. D., Martella, V., Vieira, M. J., Elia, G., .. Thiry, E. (2007). Molecular epidemiology of canine parvovirus, Europe. Emerging Infectious Diseases , 13 (8), 1222.

Decaro, Nicola, Desario, C., Amorisco, F., Losurdo, M., Colaianni, M. L., Greco, M. F., \& Buonavoglia, C. (2011). Canine parvovirus type $2 c$ infection in a kitten associated with intracranial abscess and convulsions. Journal of Feline Medicine and Surgery ,13 (4), 231-236.

Duarte, M. D., Henriques, A. M., Barros, S. C., Fagulha, T., Mendonça, P., Carvalho, P., P., Monteiro, M., Fevereiro, M., Basto, M.P., Rosalino, L.M., Barros, T., Bandeira, V., Fonseca, C., Cunha, M. V. (2013). Snapshot of Viral Infections in Wild Carnivores Reveals Ubiquity of Parvovirus and Susceptibility of Egyptian Mongoose to Feline Panleukopenia Virus. PLoS ONE , 8 (3), e59399.

Dunstone, N., Durbin, L., Wyllie, I., Freer, R., Jamett, G. A., Mazzolli, M., \& Rose, S. (2002). Spatial organization, ranging behaviour and habitat use of the kodkod (Oncifelis guigna) in southern Chile. Journal of Zoology , 257 (1), 1-11. 
Echeverria, C., Coomes, D. A., Hall, M., \& Newton, A. C. (2008). Spatially explicit models to analyze forest loss and fragmentation between 1976 and 2020 in southern Chile. Ecological Modelling,212 (3-4), 439-449.

Echeverría, C., Coomes, D., Salas, J., Rey-Benayas, J. M., Lara, A., \& Newton, A. (2006). Rapid deforestation and fragmentation of Chilean temperate forests. Biological Conservation , 130 (4), 481-494.

Filoni, C., Catão-Dias, J. L., Bay, G., Durigon, E. L., Jorge, R. S. P., Lutz, H., \& Hofmann-Lehmann, R. (2006). First Evidence of Feline Herpesvirus, Calicivirus, Parvovirus, and Ehrlichia Exposure in Brazilian Free-ranging Felids. Journal of Wildlife Diseases ,42 (2), 470-477.

Foley, J. E., Swift, P., Fleer, K. A., Torres, S., Girard, Y. A., \& Johnson, C. K. (2013). Risk factors for exposure to feline pathogens in California mountain lions (Puma concolor ). Journal of Wildlife Diseases, $49(2), 279-293$.

Gálvez, N., Guillera-Arroita, G., John, F.A.V.S., Schuttler, E., Macdonald, D.W., Davies, Z.G., (2018). A spatially integrated framework for assessing socioecological drivers of carnivore decline. Journal of Applied Ecology 55 (3), 1393-1405.

Galvez, N., Hernandez, F., Laker, J., Gilabert, H., Petitpas, R., Bonacic, C., Gimona, A., Hester, A., Macdonald, D.W. (2013). Forest cover outside protected areas plays an important role in the conservation of the Vulnerable guina Leopardus guigna. Oryx 47 (2), 251-258.

Goddard, A., \& Leisewitz, A. L. (2010). Canine parvovirus. Veterinary Clinics: Small Animal Practice , 40 (6), 1041-1053.

Google Inc. (2013). Google EarthTM. Imagery date August 2013. Mountain View, California.

Hansen, M. C., Potapov, P. V., Moore, R., Hancher, M., Turubanova, S. A. A., Tyukavina, A., Thau, D., Stehman, S.V., Goetz, S.J., Loveland, T. R. (2013). High-resolution global maps of 21st-century forest cover change.Science, 342 (6160), 850-853.

Harder, T., Kenter, M., Appel, M., Roelke-Parker, M., Barrett, T., \& Osterhaus, A. (1995). Phylogenetic evidence of canine distemper virus in Serengeti's lions. Vaccine, 13 (6), 521-523.

Heilmayr, R., Echeverria, C., Fuentes, R., Lambin, E.F. (2016). A plantation-dominated forest transition in Chile. Applied Geography, 75 , 71-82.

Hofmann-Lehmann, R., Fehr, D., Grob, M., Elgizoli, M., Packer, C., Martenson, J. S., O’Brien, S.J., Lutz, H. (1996). Prevalence of antibodies to feline parvovirus, calicivirus, herpesvirus, coronavirus, and immunodeficiency virus and of feline leukemia virus antigen and the interrelationship of these viral infections in free-ranging lions in east Africa. Clinical and Diagnostic Laboratory Immunology ,3 (5), 554-562.

Hong, C., Decaro, N., Desario, C., Tanner, P., Pardo, M. C., Sanchez, S., Buonavoglia, C., Saliki, J. T. (2007). Occurrence of canine parvovirus type 2c in the United States. Journal of Veterinary Diagnostic Investigation, 19 (5), 535-539.

Hosmer Jr, David W., Stanley Lemeshow, and Rodney X (2013). Sturdivant.Applied logistic regression. Vol. 398. John Wiley \& Sons.

Ikeda, Y. (2002). Feline Host Range of Canine parvovirus: Recent Emergence of New Antigenic Types in Cats. Emerging Infectious Diseases , 8 (4), 341-346.

Instituto Nacional de Estadistica (INE), (2017). Cited, August, 2019. URL http://www.ine.cl/estadisticas/medioambiente/informes-anuales, n.d.

Kapil, S., Cooper, E., Lamm, C., Murray, B., Rezabek, G., Johnston, L., Campbell, G., Johnson, B. (2007). Canine parvovirus types 2c and 2b circulating in North American dogs in 2006 and 2007. Journal of Clinical Microbiology , 45 (12), 4044-4047. 
Laurenson, K., Sillero-Zubiri, C., Thompson, H., Shiferaw, F., Thirgood, S., \& Malcolm, J. (1998). Disease as a threat to endangered species: Ethiopian wolves, domestic dogs and canine pathogens. Animal Conservation Forum , 1 , 273-280. Cambridge University Press.

Llanos-Soto, S., Gonzalez-Acuna, D., Llanos-Soto, S., \& Gonzalez-Acuna, D. (2019). Conocimiento acerca de los patogenos virales y bacterianos presentes en mamiferos silvestres en Chile: Una revision sistematica.Revista Chilena de Infectologia , 36 (1), 43-67.

Meli, M. L., Cattori, V., Martinez, F., Lopez, G., Vargas, A., Simon, M. A., .. Lutz, H. (2009). Feline Leukemia Virus and Other Pathogens as Important Threats to the Survival of the Critically Endangered Iberian Lynx (Lynx pardinus ). PLoS ONE , 4 (3), e4744.

Millan, J., Lopez-Bao, J. V., Garcia, E. J., Oleaga, A., Llaneza, L., Palacios, V., de la Torre, A., Rodriguez, A., Dubovi, E.J., Esperon, F. (2016). Patterns of Exposure of Iberian Wolves (Canis lupus ) to Canine Viruses in Human-Dominated Landscapes. EcoHealth ,13 (1), 123-134.

Millan, J., \& Rodriguez, A. (2009). A serological survey of common feline pathogens in free-living European wildcats (Felis silvestris ) in central Spain. European Journal of Wildlife Research , 55 (3), 285-291.

Ministerio de Bienes Nacionales website. (2019). Cited June. 2020. (http://www.ide.cl/descarga/capas/advanced-search/92.html)., n.d.

Mochizuki, M, Gabriel, M. C. S. A. N., Nakatani, H., \& Yoshida, M. (1993). Comparison of polymerase chain reaction with virus isolation and haemagglutination assays for the detection of canine parvoviruses in faecal specimens. Research in Veterinary Science , 50 , 60-63.

Mochizuki, M, Horiuchi, M., Hiragi, H., San Gabriel, M. C., Yasuda, N., \& Uno, T. (1996). Isolation of canine parvovirus from a cat manifesting clinical signs of feline panleukopenia. Journal of Clinical Microbiology , 34 (9), 2101-2105.

Mora, M., Napolitano, C., Ortega, R., Poulin, E., \& Pizarro-Lucero, J. (2015). Feline immunodeficiency virus and feline leukemia virus infection in free-ranging guignas (Leopardus guigna) and sympatric domestic cats in human perturbed landscapes on Chiloe Island, Chile. Journal of Wildlife Diseases , 51 (1), 199-208.

Nakamura, M., Tohya, Y., Miyazawa, T., Mochizuki, M., Phung, H. T. T., Nguyen, N. H., Huynh, L.M.T., Nguyen, L.T., Nguyen, P.N., Nguyen, P. V. (2004). A novel antigenic variant of canine parvovirus from a Vietnamese dog. Archives of Virology , 149 (11), 2261-2269.

Napolitano, C., Johnson, W.E., Sanderson, J., O'Brien, S.J., Rus Hoelzel, A., Freer, R., Dunstone, N., Ritland, K., Ritland, C.E., Poulin, E. (2014). Phylogeography and population history ofLeopardus guigna, the smallest American felid.Conservation. Genetics , 15 (3), 631-653.

Napolitano C., Galvez N., Bennett M., Acosta-Jamett G. \& Sanderson J. (2015a). Leopardus guigna. The IUCN Red List of Threatened Species.

Napolitano, C., Diaz, D., Sanderson, J., Johnson, W. E., Ritland, K., Ritland, C. E., \& Poulin, E. (2015b). Reduced Genetic Diversity and Increased Dispersal in Guigna (Leopardus guigna) in Chilean Fragmented Landscapes. Journal of Heredity , 106 (S1), 522-536.

Parrish, C.R., Aquadro, C. F., Strassheim, M. L., Evermann, J. F., Sgro, J. Y., \& Mohammed, H. O. (1991). Rapid antigenic-type replacement and DNA sequence evolution of canine parvovirus. Journal of Virology ,65 (12), 6544-6552.

Parrish, C.R., Have, P., Foreyt, W. J., Evermann, J. F., Senda, M., \& Carmichael, L. E. (1988). The global spread and replacement of canine parvovirus strains. Journal of General Virology, 69 (5), 1111-1116.

Parrish, C.R., Holmes, E. C., Morens, D. M., Park, E.-C., Burke, D. S., Calisher, C. H., Laughlin, C.A., Saif, L.J., Daszak, P. (2008). Cross-species virus transmission and the emergence of new epidemic diseases. Microbiol. Mol. Biol. Rev., 72 (3), 457-470. 
Parrish, Colin R., \& Kawaoka, Y. (2005). The origins of new pandemic viruses: The acquisition of new host ranges by canine parvovirus and influenza A viruses. Annual Review of Microbiology , 59 , 553-586.

Parrish, Colin R., O'Connell, P. H., Evermann, J. F., \& Carmichael, L. E. (1985). Natural variation of canine parvovirus. Science, 230 (4729), 1046-1048.

Perez, R., Francia, L., Romero, V., Maya, L., Lopez, I., \& Hernandez, M. (2007). First detection of canine parvovirus type 2c in South America. Veterinary Microbiology , 124 (1-2), 147-152.

Pfeiffer, D., Robinson, T.P., Stevenson, M., Stevens, K.B., Rogers, D.J., \& Clements, A.C. (2008). Spatial analysis in epidemiology .142 ,10, 1093. Oxford: Oxford University Press.

Posada, D., \& Buckley, T. R. (2004). Model selection and model averaging in phylogenetics: Advantages of Akaike information criterion and Bayesian approaches over likelihood ratio tests. Systematic Biology , 53 (5), 793-808.

R Development Core Team 3.0.1. (2013). A Language and Environment for Statistical Computing; R Foundation for Statistical Computing: Viena, Austria.

Riley, S. P., Foley, J., \& Chomel, B. (2004). Exposure to feline and canine pathogens in bobcats and gray foxes in urban and rural zones of a national park in California. Journal of Wildlife Diseases ,40 (1), 11-22.

Roelke-Parker, M. E., Munson, L., Packer, C., Kock, R., Cleaveland, S., Carpenter, M., O'brien, S.J., Pospischil, A., Hofmann-Lehmann, R., Lutz, H. (1996). A canine distemper virus epidemic in Serengeti lions (Panthera leo ). Nature, 379 (6564), 441.

Ronquist, F., \& Huelsenbeck, J. P. (2003). MrBayes 3: Bayesian phylogenetic inference under mixed models. Bioinformatics ,19 (12), 1572-1574.

Rubio, A., Fredes, F., \& Bonacic, C. (2013). Serological and parasitological survey of free-ranging culpeo foxes (Lycalopex culpaeus ) in the Mediterranean biodiversity hotspot of central Chile.Journal of Animal and Veterinary Advances, 12, 1445-1449.

Sacristan I, Acuna F, Aguilar E, Garcia S, Lopez MJ, Cevidanes A, Cabello J, Hidalgo-Hermoso E, Johnson WE, Poulin E, Millan J, Napolitano C. (2019). Assessing cross-species transmission of hemoplasmas at the wild-domestic felid interface in Chile using genetic and landscape variables analysis. Scientific Reports 9:16816.

Sanderson, J., Sunquist, M. E., \& W. Iriarte, A. (2002). Natural history and landscape-use of guignas (Oncifelis guigna ) on Isla Grande de Chiloe, Chile. Journal of Mammalogy , 83 (2), 608-613.

Santos, N., Almendra, C., \& Tavares, L. (2009). Serologic Survey for Canine Distemper Virus and Canine Parvovirus in Free-ranging Wild Carnivores from Portugal. Journal of Wildlife Diseases ,45 (1), 221-226.

Schulz, J. J., Cayuela, L., Echeverria, C., Salas, J., \& Benayas, J. M. R. (2010). Monitoring land cover change of the dryland forest landscape of Central Chile (1975-2008). Applied Geography , 30 (3), 436-447.

Schuttler, E., Klenke, R., Galuppo, S., Castro, R. A., Bonacic, C., Laker, J., \& Henle, K. (2017). Habitat use and sensitivity to fragmentation in America's smallest wildcat. Mammalian Biology ,86 , 1-8.

Shackelton, L. A., Parrish, C. R., Truyen, U., \& Holmes, E. C. (2005). High rate of viral evolution associated with the emergence of carnivore parvovirus. Proceedings of the National Academy of Sciences ,102 (2), 379384.

Sillero-Zubiri, C., King, A. A., \& Macdonald, D. W. (1996). Rabies and mortality in Ethiopian wolves (Canis simensis ). Journal of Wildlife Diseases , 32 (1), 80-86.

Stamatakis, A., Hoover, P., \& Rougemont, J. (2008). A rapid bootstrap algorithm for the RAxML web servers. Systematic Biology ,57 (5), 758-771. 
Steinel, A, Munson, L., van Vuuren, M., \& Truyen, U. (2000). Genetic characterization of feline parvovirus sequences from various carnivores. The Journal of General Virology , 81 (Pt 2), 345-350.

Steinel, A., Parrish, C. R., Bloom, M. E., \& Truyen, U. (2001). Parvovirus Infections in Wild Carnivores. Journal of Wildlife Diseases , 37 (3), 594-607.

Streck, A. F., Ruster, D., Truyen, U., \& Homeier, T. (2013). An updated TaqMan real-time PCR for canine and feline parvoviruses. Journal of Virological Methods , 193 (1), 6-8.

Tabar, M. D., Altet, L., Francino, O., Sanchez, A., Ferrer, L., Roura, X. (2008). Vector-borne infections in cats: molecular study in Barcelona area (Spain). Veterinary Parasitology . 151, 332-336.

Teare, J. A. (2002). Reference ranges for physiological values in captive wildlife. International Species Information System, Apple Valley, Minnesota .

Thorne, E. T., \& Williams, E. S. (1988). Disease and endangered species: The black-footed ferret as a recent example. Conservation Biology , 2 (1), 66-74.

Touihri, L., Bouzid, I., Daoud, R., Desario, C., El Goulli, A. F., Decaro, N., .. B Bahloul, C. (2009). Molecular characterization of canine parvovirus-2 variants circulating in Tunisia. Virus Genes ,38 (2), 249-258.

Truyen, U., Addie, D., Belak, S., Boucraut-Baralon, C., Egberink, H., Frymus, T., Gruffydd-Jones, T., Hartmann, K., Hosie, M.J., Lloret, A. (2009). Feline panleukopenia. ABCD guidelines on prevention and management. Journal of Feline Medicine E Surgery , 11 (7), 538-546.

Truyen, U. W. E., Evermann, J. F., Vieler, E., \& Parrish, C. R. (1996). Evolution of Canine Parvovirus Involved Loss and Gain of Feline Host Range. Virology , 189 (0021), 186-189.

Villatoro, F. J., Sepulveda, M. A., Stowhas, P., \& Silva-Rodriguez, E. A. (2016). Urban dogs in rural areas: Human-mediated movement defines dog populations in southern Chile. Preventive Veterinary Medicine, $135,59-66$.

Wilson, K., Newton, A., Echeverria, C., Weston, C., \& Burgman, M. (2005). A vulnerability analysis of the temperate forests of south-central Chile. Biological Conservation , 122 (1), 9-21.

Zar, J.H. (1999). Biostatistical Analysis,4 thed. Prentice Hall, Upper Saddle River.

\section{TABLES}

\begin{tabular}{lllll}
\hline Primer & Sequence (5' to 3') & Binding site* & Sense & Reference \\
\hline VPF & ATGGCACCTCCGGCAAAGA & $2285-2303$ & Forward & (Mochizuki et al., 1996) \\
VPR & TTTCTAGGTGCTAGTTGAG & $5285-5302$ & Reverse & \\
P1 & ATGAGTGATGGAGCAGTTC & $2786-2804$ & Forward & (Battilani et al., 2001) \\
P4 & AAGTCAGTATCAAATTCTT & $4200-4218$ & Reverse & \\
Primer F & TGGAACTAGTGGCACACCAA & $3454-3473$ & Forward & (Streck et al., 2013b) \\
Probe & 6FAM-CAGGTGATGAATTTGCTACAGG-BHQ1 & $3555-3576$ & Forward & \\
Primer R & AAATGGTGGTAAGCCCAATG & $3636-3655$ & Reverse & \\
M5mod & ATAACAAACCTTCTAAATCCTATATCAAAT & $4681-4709$ & Reverse & (Steinel et al., 2000) \\
\hline
\end{tabular}

Table 1. Oligonucleotide sequences targeting vp2 gene used in rt-PCR and conventional PCR assays for biological samples from wild guignas and domestic cats sampled in central-southern Chile.

*Binding site calculated with respect to the reference sequence CPV-N (GenBank accession Number M19296).

Table 2. Observed prevalence ofCarnivore protoparvovirus-1 infection in guigna (Leopardus guigna) (rtPCR) and domestic cat (conventional PCR) according to landscape composition, sex, age and study area 
across the guigna distribution range in Chile.

\begin{tabular}{|c|c|c|c|c|c|c|c|c|c|c|}
\hline & & & \multicolumn{8}{|l|}{$\%$} \\
\hline & & $\%$ & Posi- & & & & & $\%$ & & \\
\hline & & Posi- & tive & & & & & Posi- & $\%$ & $\%$ \\
\hline & $\%$ & tive & (CI & $\%$ & $\%$ & $\%$ & $\%$ & tive & Posi- & Posi- \\
\hline & Posi- & & $95 \%)$ & Posi- & Posi- & Posi- & Posi- & (CI & tive & tive \\
\hline & tive & $95 \%)$ & Con- & tive & tive & tive & tive & 95\%) & (CI & (CI \\
\hline & (CI & Frag- & tinu- & (CI & (CI & (CI & (CI & Cen- & $95 \%)$ & $95 \%)$ \\
\hline & $95 \%)$ & mented & ous & $95 \%)$ & $95 \%)$ & $95 \%)$ & $95 \%)$ & tral & South & Chiloé \\
\hline & Total & landscape & forest & Male & Female & Adult & Juvenile & area & area & Island \\
\hline \multirow[t]{4}{*}{ Guigna } & $n=98$ & $n=68$ & $n=30$ & $n=60$ & $n=38$ & $n=62$ & $n=16$ & $n=27$ & $n=17$ & $n=35$ \\
\hline & 13.3 & 14.7 & $10.0(-$ & 13.3 & 13.2 & 12.9 & 25.0 & 22.2 & 11.8 & 8.6 \\
\hline & $(6.4-$ & (6.0- & $13.9-$ & $(4.5-$ & (19.0- & $(4.3-$ & $(1.2-$ & (5.4- & $(-5.3-$ & $(-1.2-$ \\
\hline & 20.1) & 23.3) & 21.4) & $22.2)$ & 24.4) & 21.5) & 48.8) & 39.0) & 28.8) & \\
\hline \multirow{2}{*}{$\begin{array}{l}\text { Domestic } \\
\text { cat }\end{array}$} & $n=262$ & NA & NA & $n=133$ & $n=129$ & $n=226$ & $n=36$ & $n=43$ & $n=88$ & $n=71$ \\
\hline & $\begin{array}{l}6.1 \\
(3.2-9.0)\end{array}$ & NA & NA & $\begin{array}{l}4.5 \\
(0.9-8.0)\end{array}$ & $\begin{array}{l}7.7(3.0- \\
12.4)\end{array}$ & $\begin{array}{l}4.4 \\
(1.7-7.1)\end{array}$ & $\begin{array}{l}16.7 \\
(3.8- \\
29.5)\end{array}$ & $\begin{array}{l}9.3(0.3- \\
18.4)\end{array}$ & $\begin{array}{l}7.9(2.2- \\
13.7)\end{array}$ & $\begin{array}{l}1.4(- \\
1.4-4.2)\end{array}$ \\
\hline
\end{tabular}

$* \mathrm{NA}=$ not analyzed.

Table 3. Characteristics (sex, age, study area) and spatial variables (land use of the buffer, percent vegetation cover, number of houses within the buffer, presence of houses within the buffer, and distance to the nearest house) of each Carnivore protoparvovirus- 1positive guigna. The Rt-PCR cycle threshold for each sample is shown.

\begin{tabular}{|c|c|c|c|c|c|c|c|c|}
\hline ID & Sex & Age & $\begin{array}{l}\text { Study } \\
\text { areas }\end{array}$ & $\begin{array}{l}\text { Landscape } \\
\text { use of the } \\
\text { buffer }\end{array}$ & $\begin{array}{l}(\%) \\
\text { vegetation } \\
\text { cover } \\
\text { within the } \\
\text { buffer }\end{array}$ & $\begin{array}{l}\text { Number of } \\
\text { houses } \\
\text { within the } \\
\text { buffer }\end{array}$ & $\begin{array}{l}\text { Presence } \\
\text { of houses } \\
\text { within the } \\
\text { buffer }\end{array}$ & $\begin{array}{l}\text { Distance } \\
\text { to the } \\
\text { nearest } \\
\text { house } \\
(\mathrm{km})\end{array}$ \\
\hline LG145 & Female & Juvenile & Central & $\begin{array}{l}\text { Fragmented } \\
\text { landscape }\end{array}$ & 9.0 & 27 & Yes & 1.5 \\
\hline LG148 & Male & Adult & $\begin{array}{l}\text { Chiloé } \\
\text { Island }\end{array}$ & $\begin{array}{l}\text { Fragmented } \\
\text { landscape }\end{array}$ & 91.4 & 39 & Yes & 0.1 \\
\hline LG171 & Male & Adult & South & $\begin{array}{l}\text { Fragmented } \\
\text { landscape }\end{array}$ & 20.8 & 329 & Yes & 0.5 \\
\hline LG131 & Male & Adult & Central & $\begin{array}{l}\text { Fragmented } \\
\text { landscape }\end{array}$ & 2.6 & 190 & Yes & 1.5 \\
\hline LG137 & Male & Adult & $\begin{array}{l}\text { Chiloé } \\
\text { Island }\end{array}$ & $\begin{array}{l}\text { Fragmented } \\
\text { landscape }\end{array}$ & 64.9 & 468 & Yes & 0.2 \\
\hline LG081 & Female & Adult & $\begin{array}{l}\text { Chiloé } \\
\text { Island }\end{array}$ & $\begin{array}{l}\text { Fragmented } \\
\text { landscape }\end{array}$ & 18.2 & 7 & Yes & 17.6 \\
\hline LG186 & Male & Adult & South & $\begin{array}{l}\text { Fragmented } \\
\text { landscape }\end{array}$ & 72.9 & 51 & Yes & 0.1 \\
\hline LG176 & Male & Adult & Austral & $\begin{array}{l}\text { Continuous } \\
\text { forest }\end{array}$ & 85.5 & 3 & Yes & 0.1 \\
\hline LG165 & Female & Juvenile & Central & $\begin{array}{l}\text { Fragmented } \\
\text { landscape }\end{array}$ & 6.4 & 102 & Yes & 0.3 \\
\hline
\end{tabular}




\begin{tabular}{|c|c|c|c|c|c|c|c|c|}
\hline ID & Sex & Age & $\begin{array}{l}\text { Study } \\
\text { areas }\end{array}$ & $\begin{array}{l}\text { Landscape } \\
\text { use of the } \\
\text { buffer }\end{array}$ & $\begin{array}{l}(\%) \\
\text { vegetation } \\
\text { cover } \\
\text { within the } \\
\text { buffer }\end{array}$ & $\begin{array}{l}\text { Number of } \\
\text { houses } \\
\text { within the } \\
\text { buffer }\end{array}$ & $\begin{array}{l}\text { Presence } \\
\text { of houses } \\
\text { within the } \\
\text { buffer }\end{array}$ & $\begin{array}{l}\text { Distance } \\
\text { to the } \\
\text { nearest } \\
\text { house } \\
(\mathrm{km})\end{array}$ \\
\hline LG166 & Female & Juvenile & Central & $\begin{array}{l}\text { Fragmented } \\
\text { landscape }\end{array}$ & 52.7 & 18 & Yes & 0.2 \\
\hline LG098 & Male & Unknown & Austral & $\begin{array}{l}\text { Continuous } \\
\text { forest }\end{array}$ & 60.4 & 0 & No & 11.7 \\
\hline LG173 & Female & Adult & Central & $\begin{array}{l}\text { Fragmented } \\
\text { landscape }\end{array}$ & 5.6 & 56 & Yes & 0.0 \\
\hline LG174 & Male & Juvenile & Central & $\begin{array}{l}\text { Continuous } \\
\text { forest }\end{array}$ & 21.6 & 183 & Yes & 0.8 \\
\hline
\end{tabular}

Table 4. Summary of Carnivore protoparvovirus-1 nucleotide sequence types detected in sampled guignas and domestic cats and percentage of similarity by BLAST search of NCBI database.

GenBank sequence accession number

Carnivore protoparvovirus-1 sequence $(v p 2)$

Host species

Guigna (LG145) *MT367584

Domestic cat $($ GDAY17) *MT367582

Domestic cat (GDNH15) *MT367581

Domestic cat $($ GDNH21) *MT367580

Domestic cat (GDRM19) *MT367579

Domestic cat (GD15038) *MT367583

\section{Percentage of identity by BLAST analysis}

Canine parvovirus 2c isolate MX-TAM3.

KY818892. Canis lupus familiaris. Mexico. $99.35 \%$

Canine parvovirus 2c isolate MX-MEX71.

KY818854. Canis lupus familiaris. Mexico. $99.59 \%$

Feline panleukopenia virus isolate 193/70.

X55115. Felis silvestris catus. Australia. 100\%

Canine parvovirus 2 isolate RDPV-17-JL-3.

MH581185. Nyctereutes procyonoides viverrinus.

China. $99.73 \%$

Canine parvovirus 2a isolate Tete. KM236573.

Canis lupus familiaris. Argentina. 99.83\%

Canine parvovirus 2 isolate MX-VACVBC/17.

KY921606. Canis lupus familiaris. Mexico.

$99.86 \%$

Table 5. Hematological parameters (minimum, median, maximum and 95\% CI) ofCarnivore protoparvovirus1 real time PCR-positive and negative guignas.

\section{Carnivore}

pro-

topar-

vovirus

Red

1

blood

cells HemoglobilfematocrimCV

White

blood Segmented

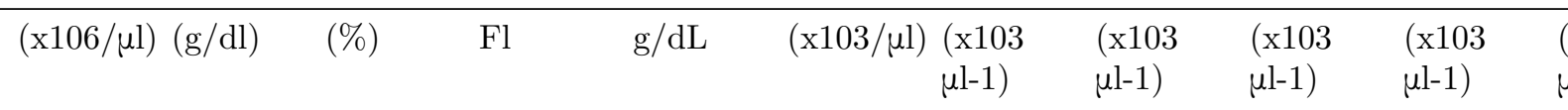




\begin{tabular}{|c|c|c|c|c|c|c|c|c|c|c|c|}
\hline $\begin{array}{l}\text { Carnivo } \\
\text { pro- } \\
\text { topar- } \\
\text { vovirus } \\
1\end{array}$ & & $\begin{array}{l}\text { Red } \\
\text { blood } \\
\text { cells }\end{array}$ & Hemo & jiftema & iMCV & MCHM & $\begin{array}{l}\text { White } \\
\text { blood } \\
\text { cells }\end{array}$ & $\begin{array}{l}\text { Segm } \\
\text { neut }\end{array}$ & $\begin{array}{l}\mathrm{d} \\
\mathrm{ILym}\end{array}$ & yłeonoc & Eosinophill \\
\hline PCR & $n$ & 4 & 4 & 4 & 4 & 4 & 4 & 4 & 4 & 4 & 4 \\
\hline & Minimum & 5.9 & 10.8 & 33.0 & 54.0 & 30.5 & 6.8 & 5.4 & 1.2 & 0.13 & 0.0 \\
\hline & Median & 7.1 & 12.4 & 40.0 & 57.0 & 31.2 & 12.8 & 7.8 & 3.4 & 0.44 & 0.09 \\
\hline & Maximun & 17.4 & 13.6 & 44.2 & 60.0 & 32.7 & 15.2 & 10.8 & 5.3 & 0.86 & 0.30 \\
\hline & $95 \%$ & $5.8-$ & $10.5-$ & 31.9- & $52.9-$ & $29.8-$ & $5.6-$ & $4.1-$ & $0.6-$ & - & - \\
\hline & CI & 8.0 & 14.2 & 46.7 & 61.1 & 32.9 & 18.1 & 11.9 & 6.0 & $\begin{array}{l}0.002- \\
0.94\end{array}$ & $\begin{array}{l}0.09- \\
0.33\end{array}$ \\
\hline PCR & $n$ & 15 & 15 & 15 & 14 & 14 & 15 & 14 & 14 & 13 & 13 \\
\hline & Minimum & 1.110 & 10.0 & 33.0 & 46.0 & 27.0 & 3.8 & 1.9 & 0.4 & 0.06 & 0.0 \\
\hline & Median & 6.920 & 13.5 & 42.1 & 56.5 & 32.0 & 10.2 & 6.7 & 1.8 & 0.19 & 0.05 \\
\hline & Maximun & 9.310 & 18.9 & 60.0 & 65.0 & 39.8 & 21.7 & 10.8 & 11.4 & 0.86 & 0.61 \\
\hline & $95 \%$ & $6.0-$ & $12.6-$ & $38.9-$ & $52.7-$ & $30.3-$ & $7.1-$ & $5.2-$ & $1.2-$ & $0.13-$ & - \\
\hline & CI & 8.2 & 15.0 & 47.2 & 58.7 & 33.8 & 12.7 & 8.6 & 4.6 & 0.43 & $\begin{array}{l}0.001- \\
0.24\end{array}$ \\
\hline
\end{tabular}

Table 6. Biochemical parameters (minimum, median, maximum and 95\% CI) of Carnivore protoparvovirus-1 PCR-positive and negative guignas.

\begin{tabular}{|c|c|c|c|c|c|c|c|c|c|c|c|c|c|}
\hline $\begin{array}{l}\text { Carnivo } \\
\text { Pro- } \\
\text { topar- } \\
\text { vovirus } \\
1\end{array}$ & & $\mathrm{TP}$ & Albumin & Globulin & TBIL & ALT & FA & GGT & $\mathrm{AST}$ & Calcium & Phospho & resseatini & nBUN \\
\hline \multirow{6}{*}{$\begin{array}{l}\text { PCR } \\
\text { posi- } \\
\text { tive } \\
\text { guignas }\end{array}$} & $n$ & $\begin{array}{l}\mathrm{g} / \mathrm{dL} \\
4\end{array}$ & $\begin{array}{l}\mathrm{g} / \mathrm{dL} \\
4\end{array}$ & $\begin{array}{l}\mathrm{g} / \mathrm{dL} \\
4\end{array}$ & $\begin{array}{l}\mathrm{mg} / \mathrm{dL} \\
4\end{array}$ & $\begin{array}{l}\mathrm{IU} / \mathrm{L} \\
4\end{array}$ & $\begin{array}{l}\mathrm{IU} / \mathrm{L} \\
4\end{array}$ & $\begin{array}{l}\mathrm{IU} / \mathrm{L} \\
4\end{array}$ & $\begin{array}{l}\mathrm{IU} / \mathrm{L} \\
4\end{array}$ & $\begin{array}{l}\mathrm{mg} / \mathrm{dL} \\
4\end{array}$ & $\begin{array}{l}\mathrm{mg} / \mathrm{dL} \\
4\end{array}$ & $\begin{array}{l}\mathrm{mg} / \mathrm{dL} \\
4\end{array}$ & $\begin{array}{l}\mathrm{mg} / \\
4\end{array}$ \\
\hline & Minimur & $\mathrm{n} 5.9$ & 2.1 & 1.6 & 0.2 & 25.8 & 40.0 & 1.6 & 27.6 & 9.1 & 5.2 & 0.2 & 9.6 \\
\hline & Median & 6.4 & 3.9 & 3.3 & 0.2 & 37.4 & 223.6 & 3.4 & 51.0 & 9.6 & 6.4 & 0.9 & 38.8 \\
\hline & Maximu & $\mathrm{n} 8.4$ & 4.3 & 4.6 & 0.6 & 47.0 & 389.8 & 4.3 & 162.0 & 9.8 & 10.0 & 1.1 & 61.3 \\
\hline & $95 \%$ & $5.0-$ & $2.0-$ & $0.7-$ & $0.01-$ & $22.0-$ & - & $1.1-$ & - & $9.0-$ & $3.6-$ & $0.1-$ & $3.3-$ \\
\hline & CI & 8.6 & 5.2 & 5.7 & 0.7 & 51.8 & $\begin{array}{l}93.3- \\
31.8\end{array}$ & 5.3 & $\begin{array}{l}23.6- \\
69.4\end{array}$ & 10.0 & 10.4 & 1.4 & 70.9 \\
\hline \multirow{2}{*}{$\begin{array}{l}\text { PCR } \\
\text { nega- } \\
\text { tive } \\
\text { guignas }\end{array}$} & $n$ & 8 & 8 & 8 & 8 & 9 & 8 & 7 & 9 & 9 & 9 & 9 & 9 \\
\hline & \multicolumn{2}{|c|}{ Minimum5.8 } & 2.2 & 1.9 & 0.1 & 6.4 & 35.0 & 2.0 & 36.0 & 1.8 & 1.6 & 0.4 & 14 \\
\hline
\end{tabular}




\begin{tabular}{|c|c|c|c|c|c|c|c|c|c|c|c|c|c|}
\hline $\begin{array}{l}\text { Carnivor } \\
\text { Pro- } \\
\text { topar- } \\
\text { vovirus } \\
1\end{array}$ & & $\mathrm{TP}$ & Albumin & Globulir & a TBIL & ALT & FA & GGT & AST & Calcium & Phos & rifiseat & inBUN \\
\hline & Median & 7.2 & 4.3 & 3.4 & 0.3 & 42.0 & 80.40 & 2.9 & 150.0 & 9.5 & 6.0 & 1.1 & 49.0 \\
\hline & Maximu & $\mathrm{m} 11.2$ & 4.8 & 6.8 & 0.4 & 182.0 & 8000 & 4.0 & 296.0 & 10.8 & 13.6 & 29.0 & 79.0 \\
\hline & $95 \%$ & $6.2-$ & $3.4-$ & $2.3-$ & $0.2-$ & $17.7-$ & - & 2.1- & 69.1- & $6.7-$ & $4.0-$ & - & 29.9 \\
\hline & CI & 9.1 & 4.7 & 4.9 & 0.3 & 7.5 & $\begin{array}{l}1251- \\
422\end{array}$ & 3.6 & 211.4 & 10.8 & 9.0 & $\begin{array}{l}3.0- \\
11.3\end{array}$ & 7.6 \\
\hline
\end{tabular}

Table 7. Hematological parameters of Carnivore protoparvovirus-1 PCR-positive and negative guignas and normal hematological values of Geoffroy's Cat (Leopardus geoffroyi), the most closely genetically related species to the guigna.

\begin{tabular}{|c|c|c|c|c|c|c|c|c|c|c|c|c|c|}
\hline ID & Sex & Age & $\begin{array}{l}\text { PCR } \\
\text { status }\end{array}$ & $\begin{array}{l}\text { Red } \\
\text { blood } \\
\text { cells } \\
(\mathrm{x} 106 \\
\mu \mathrm{l}-1) \\
\end{array}$ & $\begin{array}{l}\text { Hemogl } \\
(\mathrm{g} / \mathrm{dl})\end{array}$ & $\begin{array}{l}\text { (Hilematc } \\
(\%)\end{array}$ & $\begin{array}{l}\text { Mean } \\
\text { cor- } \\
\text { pus- } \\
\text { cular } \\
\text { vol- } \\
\text { critne } \\
\text { Fl }\end{array}$ & $\begin{array}{l}\text { Mean } \\
\text { cor- } \\
\text { pus- } \\
\text { cular } \\
\text { hemog } \\
\text { concen }\end{array}$ & $\begin{array}{l}\text { White } \\
\text { blood } \\
\text { cells } \\
\text { b(iw103 } \\
\text { atleln) }\end{array}$ & $\begin{array}{l}\text { Segmen } \\
\text { neu- } \\
\text { trophil } \\
(\mathrm{x} 103 \\
\mu \mathrm{l}-1)\end{array}$ & $\begin{array}{l}\text { Lympho } \\
(\mathrm{x} 103 \\
\mu \mathrm{l}-1)\end{array}$ & $\begin{array}{l}\text { clyfonocy } \\
(\mathrm{x} 103 \\
\mu \mathrm{l}-1)\end{array}$ & $\begin{array}{l}(\mathrm{x} 1 \\
\mu \mathrm{l}-1\end{array}$ \\
\hline \multicolumn{2}{|c|}{$\begin{array}{l}\text { Leopardus } \\
\text { geof- } \\
\text { froyi }\end{array}$} & - & - & $\begin{array}{l}6.71- \\
9.25\end{array}$ & $\begin{array}{l}11.5- \\
14.9\end{array}$ & $\begin{array}{l}35.2- \\
47.8\end{array}$ & $\begin{array}{l}47- \\
55.8\end{array}$ & $\begin{array}{l}30.2- \\
35.6\end{array}$ & $\begin{array}{l}5.387- \\
14.22\end{array}$ & $\begin{array}{l}3.35- \\
9.16\end{array}$ & $\begin{array}{l}1.038- \\
3.154\end{array}$ & $\begin{array}{l}0.06- \\
0.567\end{array}$ & $\begin{array}{l}0- \\
1 .\end{array}$ \\
\hline LG029 & Female & Adult & 0 & 7.98 & 11.9 & 39.1 & 49 & 30.5 & 18.80 & 15.416 & 1.880 & 1.316 & \\
\hline LG146 & Male & Juvenile & 0 & .13 & 2.3 & 46.0 & 57 & 7.0 & 6.10 & 8.211 & 7.406 & NA & \\
\hline LG151 & Male & Juvenile & 0 & 46 & 11.9 & 38.4 & 59.4 & 31.0 & .80 & 1.976 & 1.634 & 0.190 & 0 \\
\hline LG158 & Female & Adult & 0 & 3.74 & 15.9 & 40.0 & 46 & 39. & 0.60 & 8.480 & 1.060 & 0.106 & 0 \\
\hline LG159 & Male & Juvenile & 0 & .67 & 12.0 & 38.0 & 57 & 32.0 & 0.20 & 6.426 & 2.958 & 0.102 & \\
\hline LG160 & Male & Adult & 0 & .73 & 12.8 & 39.0 & 57 & 33.0 & 7.00 & 5.460 & 1.260 & 0.140 & 0 \\
\hline LG163 & Female & Juvenile & 0 & .11 & 18.9 & 60.0 & 54 & 35. & 5.2 & 4.628 & 0.364 & 0.156 & \\
\hline LG164 & Female & Adult & 0 & .3 & 10.0 & 33.0 & 52 & 30. & 6.90 & 4.278 & 2.277 & 0.276 & 0. \\
\hline LG165 & Female & Adult & 1 & .89 & 10.8 & 33.0 & 56 & 32. & 5.20 & 9.120 & 5.320 & 0.456 & \\
\hline LG166 & Female & Adult & 1 & .89 & 12.2 & 40.0 & 58 & 30. & 6.80 & 5.372 & 1.224 & 0.136 & \\
\hline LG171 & Male & Adult & 1 & 40 & 126 & 40.0 & 54 & 31. & 10.80 & 6.588 & 3.672 & 0.432 & 0.1 \\
\hline LG172 & Male & Juvenile & 0 & 6.48 & 13.3 & 35.0 & 5 & 34 & 13.20 & 10.560 & 1.716 & 0.660 & 0 \\
\hline LG175 & Male & Juvenile & 0 & 6.92 & 1 & 45.0 & 6 & 30 & 10.24 & 7.070 & 3.120 & 0.060 & 0 \\
\hline LG176 & Male & dult & 1 & 7.32 & 13.6 & 442 & 6 & 30.8 & 14.71 & 10.800 & 3.060 & 0.860 & 0 \\
\hline LG177 & Female & Adult & 0 & 8.89 & 59 & 548 & 6 & 28.9 & 1.70 & 10.240 & 11.350 & 0.110 & 0 \\
\hline LG185 & Male & Juvenile & 0 & 44 & 20 & 350 & $\mathrm{NA}$ & $\mathrm{NA}$ & 500 & $\mathrm{NA}$ & NA & NA & $\mathrm{NA}$ \\
\hline LG190 & Male & Adult & 0 & 31 & 15.5 & 48.4 & 52 & 320 & 5.20 & 4.056 & 0.832 & 0.260 & 0.05 \\
\hline LG191 & Male & Adult & 0 & 70 & 125 & 421 & 48 & 320 & 6.40 & 4.224 & 1.920 & 0.192 & 0.0 \\
\hline LG192 & Female & Adult & 0 & 8.34 & 15.5 & 46.9 & 56 & 33.0 & 12.80 & 10.752 & 1.408 & 0.512 & 0.12 \\
\hline
\end{tabular}

$* \mathrm{NA}=$ not analyzed

Table 8. Biochemical parameters of Carnivore protoparvovirus-1 real time PCR positive and negative guignas and normal hematological values of Geoffroy's Cat (Leopardus geoffroyi ), the most closely genetically related 
species to the guigna.

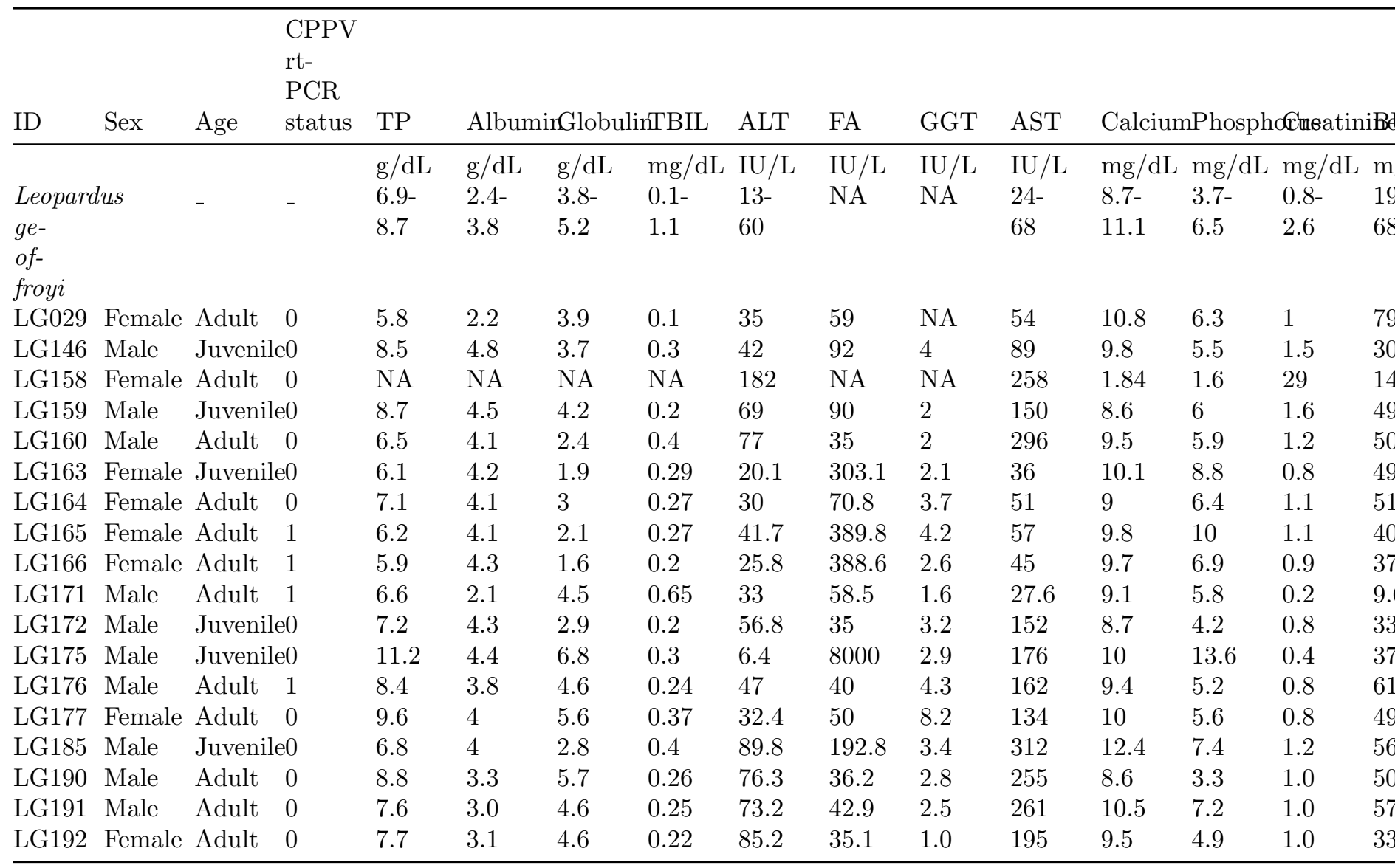

\section{FIGURE LEGENDS}

Figure 1. Map of study area, overall and per study area percent prevalence of Carnivore protoparvovirus-1 (CPPV) obtained by real time PCR and conventional PCR in guignas (white color) and by conventional PCR in domestic cats (shaded black) and the number of individuals sampled.

Figure 2 . Graphical representation of CPPV prevalence according to landscape variables (percentage of vegetation cover, distance from the sample location to the nearest house and land use), sex, age and study areas in guignas.

Figure 3. Maximum likelihood phylogenetic tree of 605 bp of thevp2 gene for guignas and domestic cats. Bootstrap values [?]70 at the nodes of the tree. Highlighted, guigna and domestic cat sequences from this study.

Figure 4. Bayesian tree of $605 \mathrm{bp}$ of the vp2 gene for guigna and domestic cat sequences. Posterior probabilities are given at the nodes of the tree, expressed as percentage, only values [?] 70 are shown. Highlighted, guigna and domestic cat sequences from this study. 

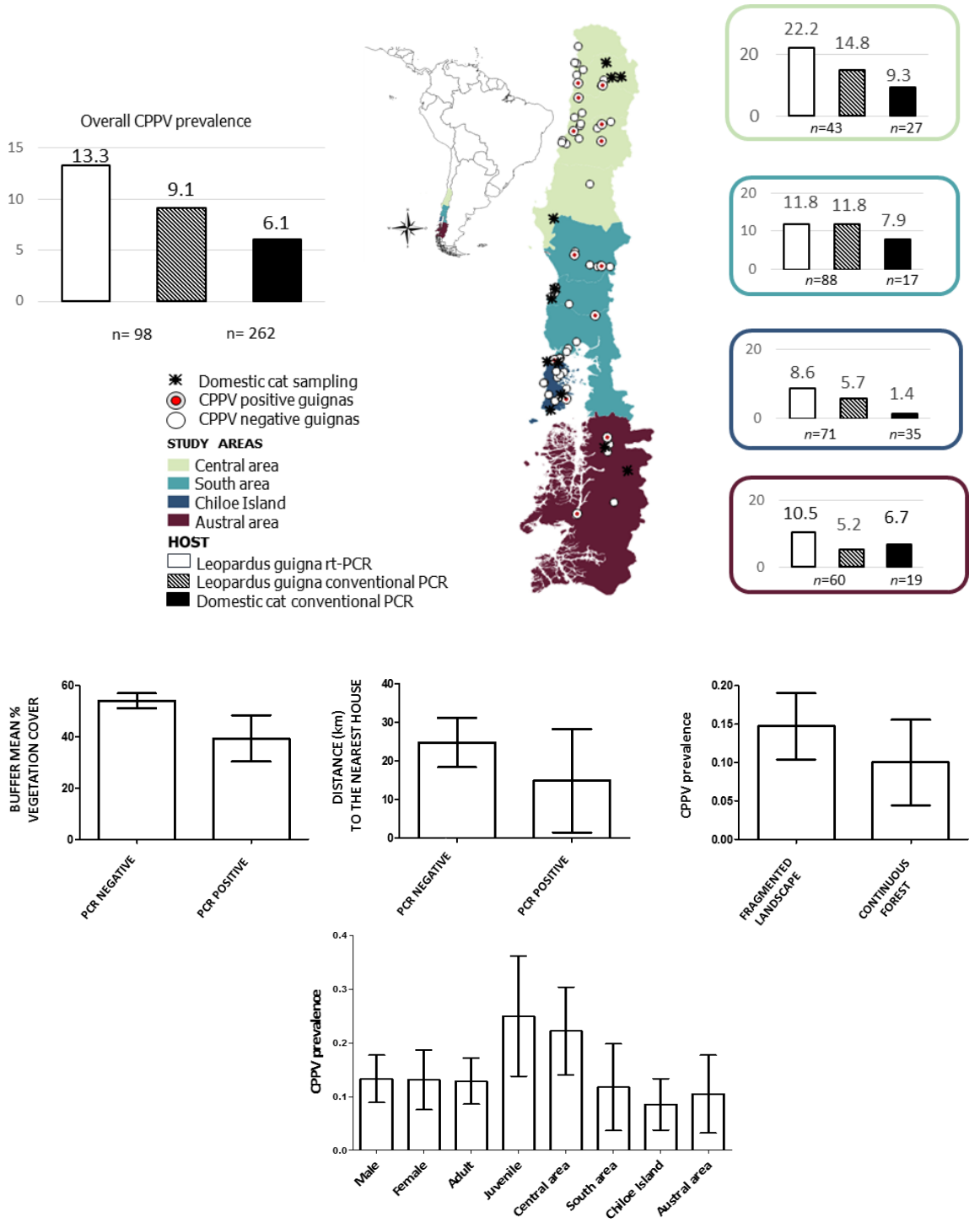
CPV 2a Tete Domestic dog Argentina KM236573

CPV 2a EC012017 Domestic dog Ecuador MG264075

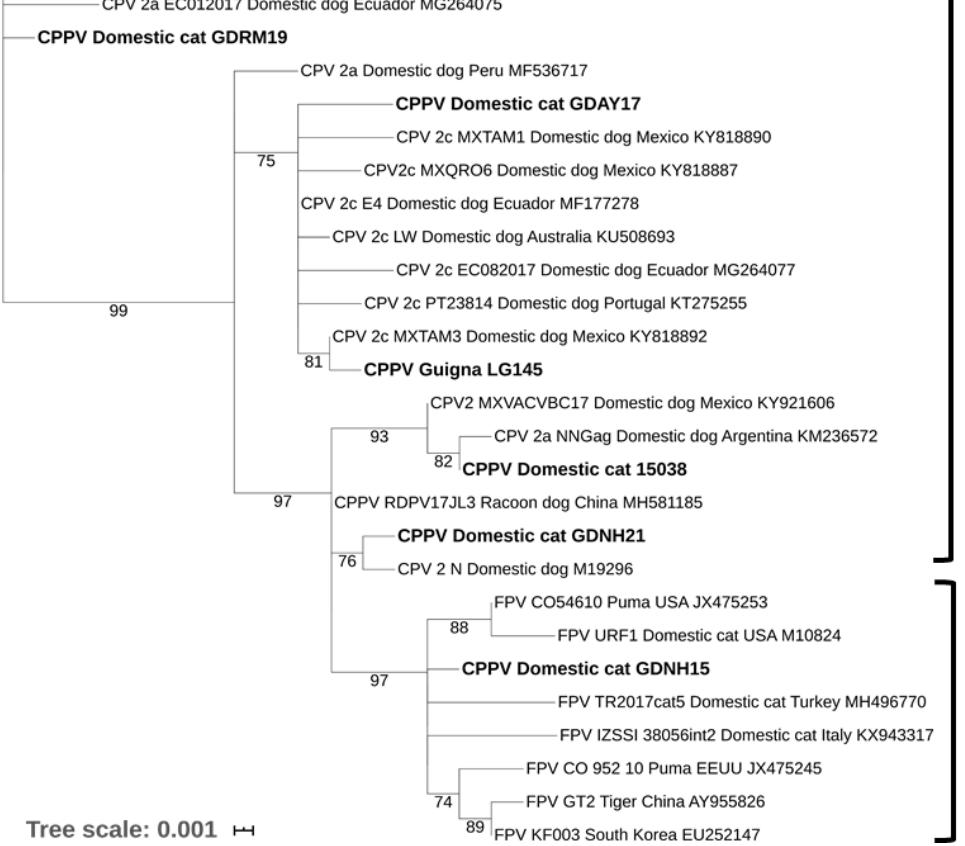

CPV-like

FPV-like

Tree scale: $0.001+\mathrm{r}$ 89 FPV KF003 South Korea EU252147

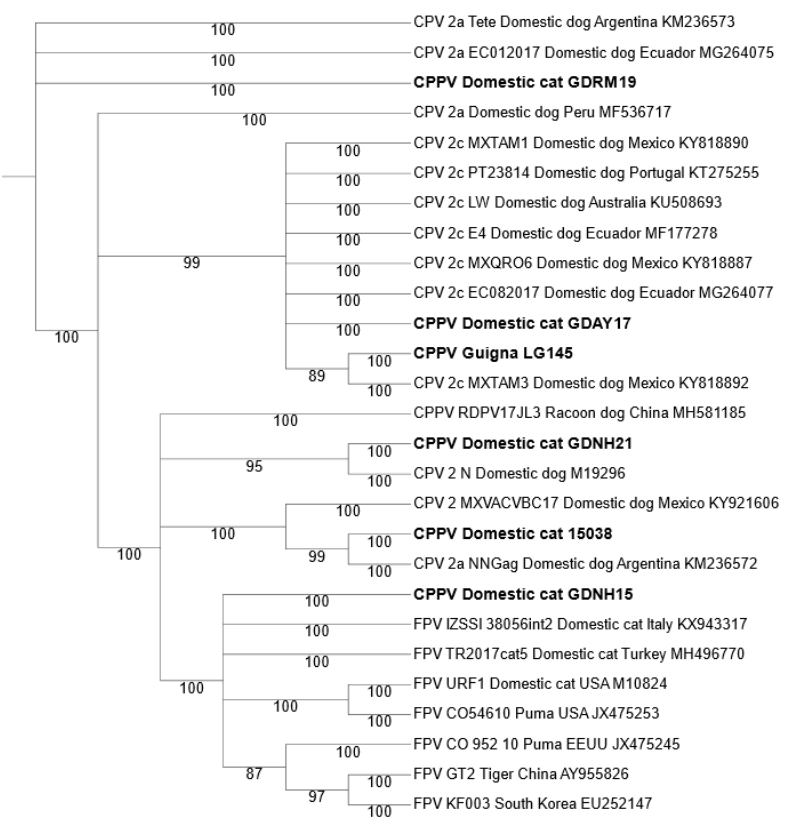

CPV-like

FPV-like 